THE KURUME MEDICAL JOURNAL

Vol. 37, p. 9-13, 1990

\title{
Subcloning and Trial of Expression of the Protein Kinase Catalytic Domain of RSV-src Gene
}

\author{
MASANOBU CHINAMI, YASUSHI OHTSU, MASASHI GOTO, KENTARO YUGE \\ HIROMICHI KUMASHIRO AND MASAHISA SHINGU
}

Department of Virology, Kurume University School of Medicine, Kurume, 830 Japan

Received for Publication December 20, 1989

\begin{abstract}
Summary: The gene of catalytic domain of the protein kinase of RSV-src was cloned into the BamHI cloning site of a translation vector $\mathrm{pET}-8 \mathrm{c}$ which containing T7 RNA polymerase promotor, and transformed BL21 (DE3) pLys S (Studier and Moffatt, 1986). The putative molecular weight of the protein was about $33 \mathrm{kd}$ as evaluated on the basis of its nucleotide size showed the identical mobility in SDS-polyacrylamide gel electrophoresis. However, yield of protein production was not high, probably, because of its instability in Escherichia coli.
\end{abstract}

Key words: $\mathrm{v}$-src $-\mathrm{pET}-8 \mathrm{c}-$ protein kinase $-\mathrm{T} 7$ - RNA polymerase promotor - transformation

\section{Introduction}

Transformation mechanisms induced by oncogenic viruses are not completely understood. Two modes of the mechanisms are considered to be involved in transformation by the viral oncogenes; amplification and point mutation of the oncogene products. However, it is unclear how the oncogene products regulate DNAreplication. A likely process leading to cell-transformation by the oncogene products is thought to be protein phosphorylation, although the specific substrates responsible for transformation are not determined. The product of the src oncogene is tyrosine specific protein kinase and p60 $\mathrm{v}$-src is phosphorylated at Tyr 417, and its phosphorylation is required for celltransformation (Hanafusa, 1977; Jove et al. 1986; Hamaguchi and Hanafusa, 1987). The protein kinase catalytic domain is located at the caroboxy terminal of the src protein, which is common to the other protein kinase family. In the protein kin- ase catalytic domain, there exisit ATP binding sites composed of the consensus sequence for nucleotide binding site, gly$\mathrm{X}$-gly-X-X-gly; these sequences are well conserved among the protein kinase family. The other portions of the protein kinase domain are also conserved (Hanks et al. 1988). The elucidation of the steric structure of the domain would be very helpful for the understanding of the mechanism of cell-transformation. Accordingly we have attempted to produce the protein kinase catalytic domain of the src gene product at a scale large enough for its steric structure analysis.

\section{Materials and Methods}

\section{Enzymes and media}

Restriction enzymes, T4 ligase, and low temperature melting agarose (agarose L) were purchased from Nippon Gene (Toyama, Japan). Src gene (pvuII-pvuII), BamHI 8 mer linker, and calf intestine 
alkaline phosphatase were purchased from Takara Shuzo (Kyoto Japan). RNAse A was purchased from Sigma Chem. Co., USA. One liter of the culture media for E. coli contained $10 \mathrm{~g} \mathrm{NZ}$ amine, $5 \mathrm{~g}$ yeast extract, $5 \mathrm{~g} \mathrm{NaCl}, 4 \mathrm{~g}$ maltose, $1 \mathrm{~g} \mathrm{NH}_{4} \mathrm{Cl}$, $3 \mathrm{~g} \mathrm{NaH}{ }_{2} \mathrm{PO}_{4}, 6 \mathrm{~g} \mathrm{Na}{ }_{2} \mathrm{HPO}_{4}$ and $1 \mathrm{ml}$ of $1 \mathrm{M} \mathrm{Mg} 2 \mathrm{SO}_{4}$; the media was autoclaved at $115^{\circ} \mathrm{C}$ for $15 \mathrm{~min}$ (Studier, 1989). Translation vector $\mathrm{pET}-8 \mathrm{c}$ and the competent cells BL21(DE3)pLysS were kindly provided by Dr. F. W. Studier of Brookhaven National Laboratory (NY, USA). Anti-src rabbit IgG was purchased from Medac (West Garmany).

\section{Purification of plasmids.}

A single colony of BL21(DE3)pLysS on the agar plate was cultured overnight in $1.5 \mathrm{ml} \mathrm{NZ} \mathrm{medium;} \mathrm{subsequently,} \mathrm{it}$ was centrifuged for $5 \mathrm{~min}$ at $6,000 \mathrm{rpm}$, at $4^{\circ} \mathrm{C}$, suspended in $0.1 \mathrm{ml}$ of $20 \mathrm{mM}$ Tris buffer containing $1 \mathrm{mg} / \mathrm{ml}$ lysozyme and incubated at RT for $10 \mathrm{~min} .200 \mu \mathrm{l}$ of $0.2 \mathrm{~N} \mathrm{NaOH}, 1 \%$ SDS (sodium dodesyl sulfate) was added to the cell suspention and incubated at $0^{\circ} \mathrm{C}$ for $10 \mathrm{~min} .150 \mu \mathrm{l}$ of $3 \mathrm{M}$ sodium acetate $(\mathrm{pH} 4.8)$ was added and the suspention was centrifuged for $30 \mathrm{~min}$, at $14,000 \mathrm{rpm}$, at $4^{\circ} \mathrm{C}$. The super natant was twice extracted with phenolchloroform, and finally, with chloroform. The water phase was precipitated by add ing two volume of $100 \%$ ethanol and washed with $70 \%$ ethanol.

\section{Construction of a translation vector}

Diagram of the procedures used in the construction of a plasmid harboring the src gene fragment is shown in Fig. 1. Src gene fragment (pvuII-pvuII) was ligated with BamHI-linker in the reaction buffer (50 mM Tris, pH 7.5, containing $100 \mathrm{ut}$ of T4 ligase, $1 \mathrm{mM}$ ATP, $10 \mathrm{mM} \mathrm{MgCl} 2$, and $20 \mathrm{mM}$ dithiothreitol). The reaction was carried out at $15^{\circ} \mathrm{C}$ for $15 \mathrm{hr}$. Then, the src gene fragment ligated with BamHIlinker was digested with excess amount

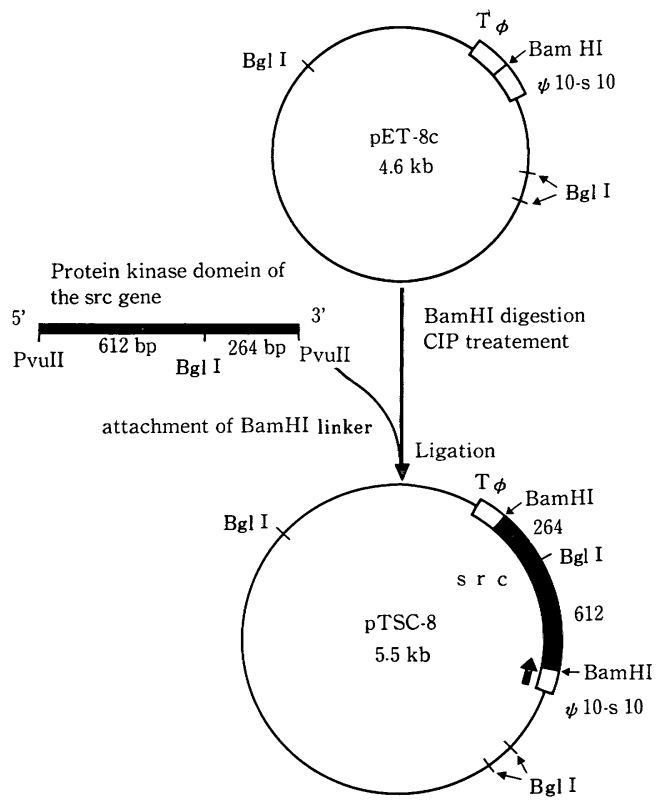

Fig. 1. Sheme of procedures for construction of a translation vector of src gene protein kinase domain.

of BamHI (100ut of BamHI) in $20 \mu \mathrm{l}$ of $50 \mathrm{mM}$ Tris (pH 7.5) containing $1 \mathrm{mM}$ $\mathrm{MgCl}_{2}$, and $20 \mathrm{mM} \mathrm{NaCl}$ ), and separated on a low temperature melting point agarose. The src gene fragment with single 8 mer BamHI-linker was isolated and extracted from the gel. pET-8c was digested with BamHI, treated with calf intestine alkaline phosphatase (CIP) and extracted with phenol and chloroform. The CIP-treated pET-8c and the src gene fragment with BamHI linker were ligated with T4 ligase as described above. Subsequently, the whole ligation mixture was used for the transformation of BL21(DE3) pLysS. The plasmid harboring the src gene fragment was designated as pTSC.

Transformation of the competent cells with plasmid DNA

Transformation was carried out accord ing to the methods described by Maniatis 
et al. (1982). The competent cells, which were cultured overnight, inoculated at the concentration of $2 \%$ into the $100 \mathrm{ml}$ of $\mathrm{NZ}$ medium and cultured at $37^{\circ} \mathrm{C}$ until the $\mathrm{OD}_{600 \mathrm{~nm}}$ of 0.3 is reached. The cell suspension was chilled at $0^{\circ} \mathrm{C}$ for $1 \mathrm{hr}$. and centrifuged for $10 \mathrm{~min}$, at $6,000 \mathrm{rpm}$, at $4^{\circ} \mathrm{C}$. The pellet of cells was suspended in 0.21 of tranformation buffer I $(30 \mathrm{mM}$ KOAc, $0.1 \mathrm{M} \mathrm{RbCl}_{2}, 10 \mathrm{mM} \mathrm{CaCl} 2$, and $50 \mathrm{mM} \mathrm{MnCl}_{2}$ ) and left for $5 \mathrm{~min}$. at $0^{\circ} \mathrm{C}$.

Expression of the src gene in E.coli and Western blot

Single colonies of pTSC were cultured in $1 \mathrm{ml}$ of $\mathrm{NZ}$ medium containing $25 \mu \mathrm{g} / \mathrm{ml}$ of chloramphenicol and $20 \mu \mathrm{g} / \mathrm{ml}$ of ampicillin, until the $\mathrm{OD}_{600 \mathrm{~nm}}$ of 1.0. At that time, $1 \mathrm{ml}$ of cell suspension was divided into two. To one portion, IPTG (isopropylthio- $\beta$ galacto-pyranoside) was added for a final concentration of $0.4 \mathrm{mM}$; to the other half the same volume of the medium was added. The cell suspentions were treated with $2 \mathrm{mg} / \mathrm{ml}$ lysozyme for $10 \mathrm{~min}$ at room temperature, freeze-thawed twice and centrifuged for $2 \mathrm{~min}$. at $10,000 \mathrm{rpm}$, at $4^{\circ} \mathrm{C}$. The samples were analyzed in $12 \%$ SDSpolyacrylamide gel electrophoresis by the Laemmli's methods (Laemmli, 1970). The bands in the gel were transferred to nitrocellulose membrane, and reacted with anti-src rabbit IgG and peroxidase-conjugated anti-rabbit IgG after washing. The bands of immunoblot were visualized with $0.4 \mathrm{mg} / \mathrm{ml}$ of OPD (orthophenylenediamine) in the presence $0.1 \%$ hydroxy peroxide.

\section{Results}

The tranlation vector $\mathrm{pET}-8 \mathrm{c}$ was constructed based on the pBR322 (Rosenberg et al. 1987). The plasmid purified as described in the methods, and applied on $1 \%$ agarose gel; a typical pattern is shown in Fig. 2. Two forms of plasmid DNAs

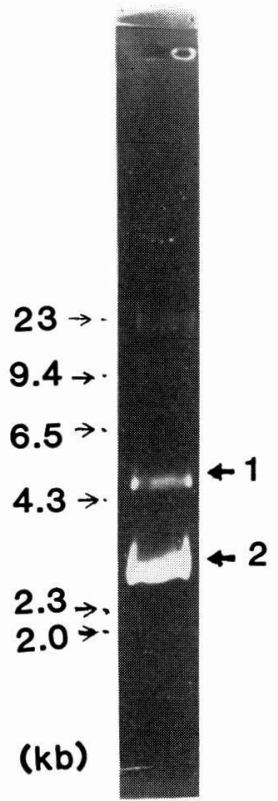

Fig. 2. Agarose gel electrophoresis pattern of purified plasmid pET-8c. Plasmid pET-8c was purified as described in the Methods and applied on $1.0 \%$ agarose gel electrophoresis. Band 1 and 2 indicated at the right side are linear and closed circular forms. DNA size markers are indicated on the left side.

are seen in this figure. The high mobility of plasmid DNA located at about $3 \mathrm{~kb}$ represents a covalently-closed circular form; the slow plasmid which is located at 4.6 $\mathrm{kb}$ represents a open circular form. BL21 (DE3)pLysS transformed with the plasmid pET-8c which was ligated by the src gene fragment at Bam HI site was plated. Colonies resistant to chloramphenicol and ampicilin were picked and the plasmid DNAs were analyzed with DNA endonuclease restriction patterns. One of the plasmids, with its src gene orderly oriented in the reading frame of $\mathrm{pET}-8 \mathrm{c}$, was designated as pTSC-8. BamHI restriction pattern of the pTSC- 8 is shown in Fig. 3; 870 bp fragment from the srcgene and $631 \mathrm{bp}$ fragment from lysozyme gene cloned in the pACYC184 (Chang and 


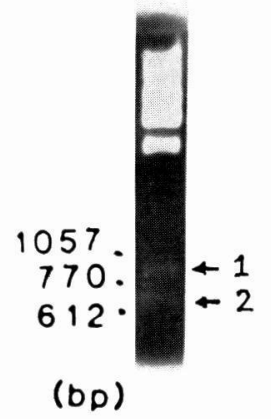

Fig. 3. Restriction pattern with BamHI of pTSC-8. Plasmid DNA from BL21(DE3) pLysS transformed with pTSC-8 was purified, digested with BamHI and applied on 1.5\% agarose gel electrophoresis. Fragment DNAs from the plasmids are indicated on the right side of the figure and size markers are on the left side.

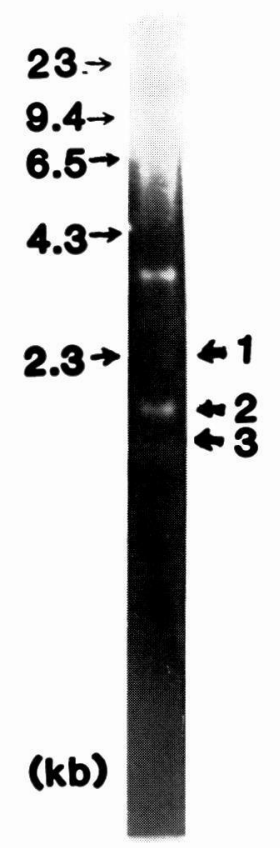

Fig. 4. Restriction pattern with BglI of pTSC-8. Plasmid pTSC- 8 was digested with BglI and separated in 1.5\% agarose gel. DNA fragments obtained from the plasmids and size markers are indicated on the right and left sides, respectively.

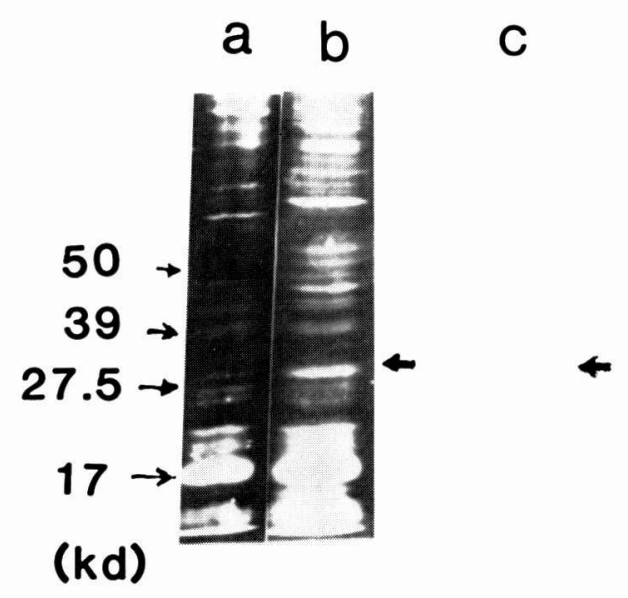

Fig. 5. SDS-polyacrylamide gel electrophoresis pattern and Western blot of the protein kinase domain of src protein expressed in E. coli. One $\mathrm{ml}$ of transformed cells with pTSC-8 was cultured for $1 \mathrm{hr}$. and further cultured over night with and without $0.4 \mathrm{mM}$ IPTG (isoprophyl- $\beta$-thiogalactopyranoside). The bands are transfered to nitrocellulose filter and reacted with anti-src antibody. a: culture without IPTG, b: culture with IPTG, c: Western blot for $\mathrm{b}$. The protein kinase domain of the src gene is indicated with an arrow on the right side and the markers of molecular weight are indicated on the left side.

Cohen, 1978) of BL21(DE3)pLysS are seen in the figure. Restriction fragments of the pTSC-8 with Bgl I exhibited sizes of $2.3,1.6,1.3$, and $0.23 \mathrm{~kb}$ (Fig. 3 ); the $0.23 \mathrm{~kb}$ fragment cannot be seen in this figure. Expression of the cloned gene was examined for the clone by SDS-PAGE, and compared in the presence and absence of IPTG (Fig. 5b and a). More $33 \mathrm{kd}$ protein was induced in the presence than in the absence of IPTG. The protein bands were transferred to nitrocellulose filter and immunoblotted with anti-src IgG by the Western blot. The band which reacted with the antibody is indicated; the band is very weak (Fig. 5c). The molecular 
weight matched with the nucleotides size of the cloned gene.

\section{Discussion}

To study how protein phosphorylation of p60 v-src specific for tyrosine residue contributes to cell-transformation, the gene was cloned into the expression vector. The fragment cloned in to $\mathrm{pET}-8 \mathrm{c}$ was confirmed by agarose gel electrophoresis and the protein expressed in BL21 (DE3) pLysS was also confirmed by Western blot. However, the yield of the protein production was not sufficient for its structure analysis. Its poor producibility by E. coli may be due to its instability and/or degradading in E. coli. Many researchers have been trying to obtain p60 v-src in E. coli or yeast, but they have not succeeded in efficient large scale of production. However, recently Varmus's group reported large scale of protein production with a mutant gene of $\mathrm{p} 60 \mathrm{c}$-src cloned in a vaculovirus vector in Sf9 cells (Morgan et al. 1989); the protein was mutated Lys at 295 to Met in the ATP binding site and has lost its capacity to bind ATP. On the other hand, a clone of the prototype of the p60 c-src showed poor yield. Thus we infer that the instability of p60 v-src, especially with respect to the presence of ATP binding site in the protein kinase domain may contribute to the instability.

\section{References}

Chang, A.C.Y. and Cohen, S.N. (1978). Construction and characterization of amplifiable multicopy DNA cloning vehicles derived from the P15A cryptic miniplasmid. J. Bacteriol. 134, 1141-1156.

Hamaguchi, M. and Hanafusa, H. (1987). Association of $\mathrm{p} 60 \mathrm{src}$ with triton X-100 resistant cellular structure correlates with morphological transformation. Proc. Natl. Acad. Sci. USA 84, 2312-2316.

HanAfusa, H. (1985). Cell transformation by RNA tumor viruses, In Comprehensive virology, vol. 10, eds. Frankel-Conrat, H. and Wagner, R.P. pp. 401-483. New York: Plenum Publishing Corp.

Hanks, S. K., Quinn, A.M. and Hunter, T. (1988). The protein kinase family: Conserved features and deduced phylogeny of the catalytic domains. Science 241, 42-52.

Jove, R., Mayor, B. J., Ida, H., Laugier, D., Poirier, F., Calothy, G., Hanafusa, T. and Hanafusa, H. (1986). Genetic analysis of p60 v-src domains involved in the induction of different cell transformation parameters. J. Virol. 60, 840-848.

LaEmmLi, U.K. (1970). Cleavage of structural proteins during the assembly of the head of bacteriophage T4. Nature 227, 680-685.

Maniatis, T., Fritsch, E.F. and Sambrook, J. (1982). Molecular Cloning: Laboratory manual. Cold Spring Harbor Laboratory, Cold spring harbor, N.Y.

Morgan, D. O., Kaplan, J.M., Bishop, J.M. and Varmus, H.E. (1989). Mitotic-specific phosphorylation of $\mathrm{p} 60$ by $\mathrm{p} 34 / \mathrm{cdc} 2$-associated protein kinase. Cell 57, 775-786.

Rosenberg, A. H., Lade, B. N., Chui, D. S., Dunn, J. J. and Studier, F. W. (1987). Vectors for selective expression of cloned DNAs by T7 RNA polymerase. Gene 56, 125-135.

Studier, F. W. and Moffat, B. A. (1986). Use of bacteriophage T7 RNA polymerase to direct selective high-level expression of cloned genes. J. Mol. Biol. 189, 113-130. 